\title{
Dnaj Homolog Subfamily A Member 1
}

National Cancer Institute

\section{Source}

National Cancer Institute. Dnal Homolog Subfamily A Member 1. NCI Thesaurus. Code C126988.

Dnaj homolog subfamily A member 1 (397 aa, $\sim 45 \mathrm{kDa}$ ) is encoded by the human DNAJA1 gene. This protein plays a role in both protein trafficking and protein folding. 